\title{
Preferensi Konsumen terhadap Produk Sayuran Organik (Studi Kasus Konsumen UD Fabela-Myfarm) di Bogor Jawa Barat
}

\author{
Consumer Preferences On Organic Vegetables (UD Fabela-Myfarm Consumer Case Study) \\ In Bogor West Java
}

\author{
Bebby Chrysanthini ${ }^{*}$, Ujang Sumarwan ${ }^{2}$, dan Amzul Rifin ${ }^{3}$
}

\author{
${ }^{1}$ Mahasiswa Program Manajemen dan Bisnis, Sekolah Bisnis Institut Pertanian Bogor \\ ${ }^{2}$ Departemen Ilmu Keluarga dan Konsumen, Fakultas Ekologi Manusia Institut Pertanian Bogor \\ ${ }^{3}$ Departemen Agribisnis, Fakultas Ekonomi dan Manajemen Institut Pertanian Bogor \\ Jl. Raya Pajajaran Bogor 16151
}

\begin{abstract}
ABSTRAK
Penelitian ini bertujuan untuk menganalisis preferensi konsumen terhadap atribut sayuran organik di Fabela-Myfarm dan merekomendasikan implikasi strategi yang dapat dilakukan Fabela-Myfarm untuk meningkatkan penjualan sayuran organik. Menggunakan teori preferensi konsumen dan teori TPB (the theory of planned behaviour). Desain penelitian ini dilakukan dengan pendekatan metode deskriptif kuantitatif. Metode pengambilan contoh dilakukan dengan teknik purpossive sampling, dengan kriteria responden yang diambil adalah 200 orang yang pernah membeli sayuran organik. Variabel pada penelitian ini terdiri dari variabel independent sikap terhadap perilaku sayuran organik $\left(\mathrm{x}_{1}\right)$, norma subjektif $\left(\mathrm{x}_{2}\right)$, persepsi pengendalian perilaku ( $\left.\mathrm{x}_{3}\right)$ dan dependen (y). Metode analisis yang digunakan adalah regresi linear berganda. Hasil penelitian menunjukan variabel sikap terhadap perilaku sayuran organik tidak memberikan pengaruh signifikan terhadap niat beli. Variabel norma subjektif memberikan pengaruh signifikan terhadap niat beli dan variabel persepsi pengendalian perilaku memberikan pengaruh signifikan terhadap niat beli. Penelitian ini memberikan implikasi manajerial bahwa strategi yang dapat diterapkan oleh UD Fabela-Myfarm untuk meningkatkan penjualan menggunakan strategi pemasaran yang terdiri dari produksi, harga, promosi, distribusi dan strategi tersebut berguna untuk mengaitkan konsumen dari sisi kuantitas, mutu, dan keseimbangan yang mampu memberikan keuntungan lebih baik.
\end{abstract}

Kata kunci: organik, preferensi konsumen, regresi linear berganda, TPB

\section{ABSTRACT}

This research aimed to analyze consumer preferences to organic-vegetables attributes in FambelaMyfarm and recommend strategic implication to increase organic vegetables sales. This research use consumer preferences theory and theory of planned behaviour, design in this research are using decriptive-quantitative approach. Sampling method used are purposive sampling to 200 samples whom have purchased organic vegetables. Independet variable on this research consist of behavioral belief $\left(\mathrm{x}_{1}\right)$, subjective norm $\left(\mathrm{x}_{2}\right)$, perceived behavioral control $\left(\mathrm{x}_{3}\right)$ to purchase intention $(\mathrm{y})$. These variable are analyzed using multiple linear regression. The results of this research shows that behavioral belief variable does not significantly affecting purchase intention. Subjective norm and perceived behavioral control variables shows significant influence to purchase intention. This research implied that FabelaMyfarm could formulized marketing strategy to increase sales by utilizing product, price, promotion, and distribution. This strategies aimed to attract consumer to increase quantity through quality, and balance to create a better profit overtime.

Key words: consumers preference, multiple linear regression, organic, TPB 


\section{PENDAHULUAN}

Pertanian organik merupakan salah satu bagian dari sektor pertanian yang mendapat perhatian besar masyarakat di negara maju maupun negara berkembang seiring dengan perubahan pola hidup masyarakat yang lebih mementingkan kualitas kesehatan, baik kesehatan manusia maupun lingkungan. Hal tersebut merupakan peluang potensi pasar yang perlu dicermati secara mendalam. Banyak negara di dunia mulai menekuni pertanian organik karena potensi besar yang terdapat pada pertanian organik ini. Pergeseran pola hidup masyarakat yang lebih mementingkan kualitas kesehatan, baik kesehatan manusia maupun kesehatan lingkungan ini (Hubeis, 2013).

Volume perdagangan produk organik di Indonesia masih rendah. Padahal, Indonesia memiliki potensi lahan pertanian yang sangat luas sekitar 107 juta hektar pada tahun 2014 dan potensi bahan baku untuk pupuk organik dalam jumlah sangat besar, antara lain bersumber dari limbah pertanian, limbah industri, limbah peternakan, sampah kota, dan rumah tangga. Menurut data Badan Pusat Statistik (BPS) Indonesia, Provinsi Jawa Barat merupakan daerah yang memiliki jumlah penduduk terbesar di Pulau Jawa. Selain itu, jumlah penduduk di Jawa Barat terus meningkat dari tahun 2013 hingga tahun 2015 (Tabel 1). Adanya potensi kebutuhan akan pupuk organik yang sangat besar menunjukkan potensi pengembangan produk organik di Jawa Barat juga sangat besar.

Tabel 1. Jumlah penduduk di Pulau Jawa Tahun 20132015

\begin{tabular}{lccc}
\hline \multirow{2}{*}{ Provinsi } & \multicolumn{3}{c}{ Jumlah Penduduk (Ribu) } \\
\cline { 2 - 4 } & 2013 & 2014 & 2015 \\
\hline DKI Jakarta & 9.969 & 10.075 & 10.177 \\
Jawa Barat & 45.340 & 46.029 & 46.709 \\
Jawa Tengah & 33.264 & 33.522 & 33.774 \\
DI Yogyakarta & 3.595 & 3.637 & 3.679 \\
Jawa Timur & 38.363 & 36.610 & 38.847 \\
Banten & 11.452 & 11.704 & 11.955 \\
\hline
\end{tabular}

Sumber: BPS (2015).

Departemen Pertanian telah mencanangkan program “Go Organik 2010". Program ini diarahkan agar masyarakat, baik petani sebagai produsen maupun masyarakat luas sebagian konsumen untuk hidup sehat. Misi dalam program Go Organik 2010 ini adalah meningkat- kan mutu hidup masyarakat dan kelestarian lingkungan alam Indonesia, dengan mendorong berkembangnya pertanian organik yang berdaya saing dan berkelanjutan. Untuk itu, pemerintah terus mendukung secara aktif pertanian organik di Indonesia dengan membentuk aturan/regulasi yang meliputi standarisasi, sertifikasi dan pengawasan. Sistem pangan organik ini telah diatur oleh pemerintah dalam Standar Nasional Indonesia (SNI) tentang pangan organik yang tertuang dalam SNI 01-6729-2010 (SNI Pangan Organik, 2010).

Hal ini dapat menjadi salah satu peluang bagi produsen dalam memasarkan produk organik. Berdasarkan data BPS Jawa Barat menunjukkan bahwa Kota Bogor merupakan kota yang memiliki jumlah pengeluaran rata-rata per kapita per bulan pada tahun 2015 paling besar dibanding kota lainnya yang ada di Jawa Barat. Pengeluaran rata-rata per kapita per bulan mencakup pengeluaran bukan makanan dan pengeluaran untuk makanan. Pengeluaran ratarata per kapita sebulan menurut kelompok sayuran/hortikultura dapat dilihat pada Gambar 1.

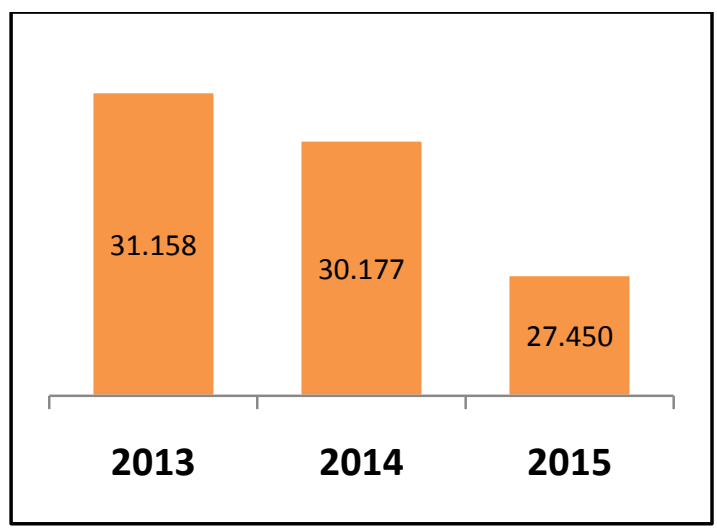

Gambar 1. Pengeluaran rata-rata per kapita sebulan provinsi Jawa Barat

Engel et al. (2012) mendefinisikan perilaku konsumen sebagai tindakan yang langsung terlibat dalam mendapatkan, mengkonsumsi dan menghabiskan produk dan jasa termasuk proses keputusan yang mendahului dan mengikuti tindakan. Hal tersebut mendorong konsumen akan memilih bahan pangan yang aman bagi kesehatan, sehingga mendorong meningkatnya permintaan produk organik.

Menurut Schiffman dan Kanuk (2004) menyatakan bahwa niat adalah suatu bentuk pikiran yang nyata dari refleksi rencana pembeli untuk membeli beberapa unit dalam jumlah tertentu dari beberapa merek yang tersedia 
dalam periode waktu tertentu. Menurut Theory of Planned Behavior dari Fishbein dan Ajzen, tindakan seseorang adalah realisasi dari keinginan atau niat seseorang untuk bertindak. Perilaku tertentu dari seorang konsumen sering kali ditentukan oleh intensi atau niat dari konsumen untuk melakukan perilaku tertentu tersebut (Sumarwan, 2011). Menurut Sumarwan et al. (2013), proses keputusan pembelian melalui tahap pengenalan kebutuhan, pencarian informasi, evaluasi alternatif, pembelian, dan evaluasi pasca pembelian.

Tujuan utama dari pertanian organik adalah mengoptimalkan kesehatan dan produktivitas mikroorganisme tanah, tumbuhan, hewan dan manusia. Sejauh ini pertanian organik disambut baik oleh banyak kalangan masyarakat, meskipun dengan pemahaman yang berbeda. Keberlanjutan pertanian organik, tidak dapat dipisahkan dengan dimensi ekonomi, selain dimensi lingkungan dan dimensi sosial. Kesadaran akan bahaya yang ditimbulkan oleh pemakaian bahan kimia dalam pertanian menjadikan pertanian organik menarik perhatian konsumen. Hal tersebut mendorong konsumen akan memilih bahan pangan yang aman bagi kesehatan, sehingga mendorong meningkatnya permintaan produk organik

UD Fabela-Myfarm adalah sebuah perusahaan yang bergerak pada bidang usaha tani, sayuran organik berskala kecil yang berkembang dengan baik karena memiliki konsumen pasti yang bersumber perorangan (kelas menengah) akan dikembangkan sebagaimana layaknya perusahaan-perusahaan yang bergerak disektor agribisnis.

Fabela-Myfarm yang berstatus UD berdiri pada tahun 2013 berlokasi di Gunung Picung Bogor Jawa Barat. Penetapan lokasi tersebut sesuai dengan karakteristik lingkungan yang membantu pertumbuhan pertanian organik. Perusahaan saat ini memasarkan produk pertaniannya di wilayah Bogor dan sekitarnya. Dengan semakin meningkatnya kebutuhan sayur organik, khususnya di wilayah Bogor dan peluang bagi perusahaan dalam memasarkan sayuran organik. Kondisi tersebut didukung dengan angka produksi sayuran di wilayah Bogor dengan peningkatan 12\% dari tahun 2013 hingga 2015, dengan jumlah produksi berturut-turut 78.640 ton pada tahun 2013 dan 88.259 ton pada tahun 2015 . Data produksi sayuran wilayah Bogor 2013-2015 dapat dilihat pada Gambar 2.

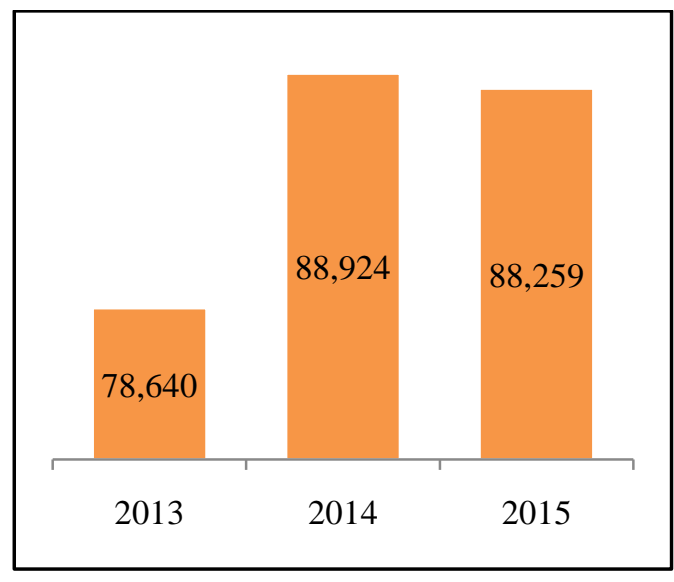

Gambar 2. Data produksi sayuran wilayah Bogor

Menurut Sumarwan (2014), suatu perusahaan harus mampu memahami perilaku konsumen dengan sebaik mungkin agar dapat memasarkan produknya dengan baik. Perusahaan dapat memperkirakan respon dari konsumen terhadap produk yang ditawarkan oleh perusahaan sehingga perusahaan dapat menerapkan strategi pemasaran yang tepat. Salah satunya dengan analisa preferensi konsumen berkaitan erat pada penilaian akan kepuasan atau ketidakpuasan terhadap produk atau jasa bahkan juga pada perusahaan (Tjiptono, 2002), agar perusahaan dapat menganalisis niat pembelian konsumen dan menyusun strategi pemasaran yang dapat meningkatkan penjulan sayuran organik.

Kepuasan konsumen terhadap sayuran organik menunjukan bahwa konsumen belum puas terhadap atribut harga dan ketersediaan sayuran di pasaran. Hasil identifikasi kepuasan menunjukkan konsumen lebih menginginkan harga yang wajar terhadap sayuran organik, hal tersebut dapat dicapai dengan cara peningkatan produksi sayuran organik. Peningkatan produktivitas dilakukan dengan cara mengefektifkan produksi sayuran organik dengan mengidentifikasi kemampuan teknis (Umar, 2004).

Berdasarkan penelitian terdahulu terdapat beberapa kajian mengenai faktor-faktor yang memengaruhi permintaan sayuran organik, namun belum ditemukan penelitian tentang preferensi konsumen terhadap pembelian sayuran organik. Penelitian yang telah dilakukan oleh Barus (2005) tentang analisis faktor-faktor yang memengaruhi permintaan beberapa sayuran Organik di PT Amani Mastra. Contoh yang digunakan dalam penelitian ini adalah 60 responden dengan mengambil contoh di Carrefour MT Haryono. Variabel-variabel yang diduga berpengaruh nyata terhadap permintaan 
sayuran organik (tomat, wortel, dan brokoli) dalam penelitian ini adalah pendapatan rumah tangga, usia, jumlah anggota keluarga, lama pendidikan formal, frekuensi pembelian, dummy harga, dummy jenis kelamin, dan dummy sumber informasi, hasil analisis regresi model yang digunakan untuk menganalisis faktor-faktor yang memengaruhi permintaan wortel, tomat, dan brokoli organik adalah linier berganda dan analisis elastisitas Diketahui bahwa untuk permintaan wortel dan tomat organik, variabel usia memiliki nilai elastisitas terbesar, yaitu 0,792 dan 1,269, sedangkan untuk permintaan brokoli organik, frekuensi pembelian memiliki nilai elastisitas yang paling besar, yaitu 0,699.

Penelitian Damayanti (2009) berjudul "Analisis Preferensi Konsumen Wortel Organik Amani Mastra di Foodmart Ekalokasari", memiliki tujuan untuk menganalisis proses pengambilan keputusan dalam pembelian wortel organik Amani Mastra dan menganalisis preferensi konsumen terhadap atribut wortel organik Amani Mastra. Penelitian menggunakan alat analisis deskriptif untuk menganalisis proses pengambilan keputusan dalam pembelian dan karakteristik konsumen, serta metode analisis konjoin untuk menganalisis preferensi konsumen terhadap atribut wortel organik Amani Mastra. Dari hasil analisis konjoin, harga merupakan atribut yang dipandang paling penting oleh responden, maka PT Amani Mastra harus mempertimbangkan untuk menyesuaikan harga dengan keinginan konsumen wortel organik. Penyesuaian harga dapat dilakukan dengan meninjau kembali biaya-biaya produksi dan operasional. Ukuran dari wortel organik juga perlu disesuaikan dengan keinginan konsumen, yaitu ukuran wortel yang besar-besar. Ketersediaan dari wortel organik juga perlu diperbanyak, agar konsumen mudah mendapatkannya.

Penelitian Sudiyanti (2009) menggunakan faktor-faktor penduga pada niat beli wanita di Indonesia terhadap produk pangan ramah lingkungan dengan pendekatan Theory of Planned Behavior. Hasil menunjukkan bahwa norma subjektif memiliki keeratan hubungan yang paling signifikan dengan niat dibandingkan dengan sikap dan kontrol perilaku. Temuan ini menunjukkan kecenderungan yang berbeda dengan Theory of Planned Behavior, dimana idealnya sikap menjadi faktor penduga utama. Sementara itu, kesulitan yang dirasakan (perceived difficulty) menjadi prediktor terkuat kedua setelah norma subyektif dalam memprediksi niat beli. Variabel ini memiliki hubungan yang signifikan negatif dan dengan niat beli konsumen. Sikap, yang idealnya memiliki keeratan paling kuat dengan niat, pada model penelitian ini hanya menjadi prediktor ketiga setelah norma subyektif dan kesulitan yang dirasakan (perceived difficulty). Penelitian ini juga menunjukkan bahwa pengetahuan konsumen wanita Indonesia akan lingkungan berada pada level rata-rata (sedang). Hasil juga menunjukan bahwa pengetahuan dapat dijadikan prediktor niat beli produk ramah lingkungan.

Model pada TPB menjadi acuan dasar pengembangan kerangka penelitian ini adalah niat beli sayuran organik. Sikap merupakan derajat kesukaan atau kesetujuan individu terhadap hal-hal yang berkaitan dengan perilaku tertentu. Variabel ini merupakan komposit dari kepercayaan (behavioral beliefs) individu terhadap perilaku tersebut dan evaluasinya terhadap hasil perilaku (outcome evaluation) tersebut. Norma subyektif adalah persepsi individu terhadap harapan orang lain (yang dianggap penting) untuk menujukkan atau tidak menunjukkan suatu perilaku (normative beliefs) dan seberapa besar keinginan individu untuk menuruti harapan orang lain tersebut (motivation to comply). Sementara itu, kontrol perilaku adalah komposit dari tingkat kepercayaan individu yang mampu mengendalikan atau menunjukkan suatu perilaku (control beliefs) dan keyakinan individu bahwa terdapat faktor pendukung atau penghambat dalam menunjukkan perilaku tersebut (perceived power) (Ajzen, 1991). Dalam mengkaji preferensi konsumen terhadap kombinasi atribut-atribut dari sayuran organik menjadi hal yang sangat penting agar mendapat pengetahuan tentang nilai kepentingan atribut yang diinginkan oleh konsumen yang menjadi target pasarnya. Analisis tersebut dilakukan melalui penelitian terhadap karakteristik konsumen, proses pengambilan keputusan dan preferensi konsumen terhadap atribut sayuran organik. Untuk mengetahui karakteristik konsumen dan proses pengambilan keputusan digunakan analisis deskriptif dan untuk mengetahui preferensi konsumen terhadap kombinasi atribut sayuran organik dan niat beli terhadap sayuran organik menggunakan analisis regresi linear berganda. Hasil penelitian ini menjadi rekomendasi kepada para unit usaha yang bergerak dalam bidang sayuran organik untuk menentukan keputusan aspek pemasaran dan produksi yang tepat. Kerangka pemikiran penelitian ditampilkan pada Gambar 3. 


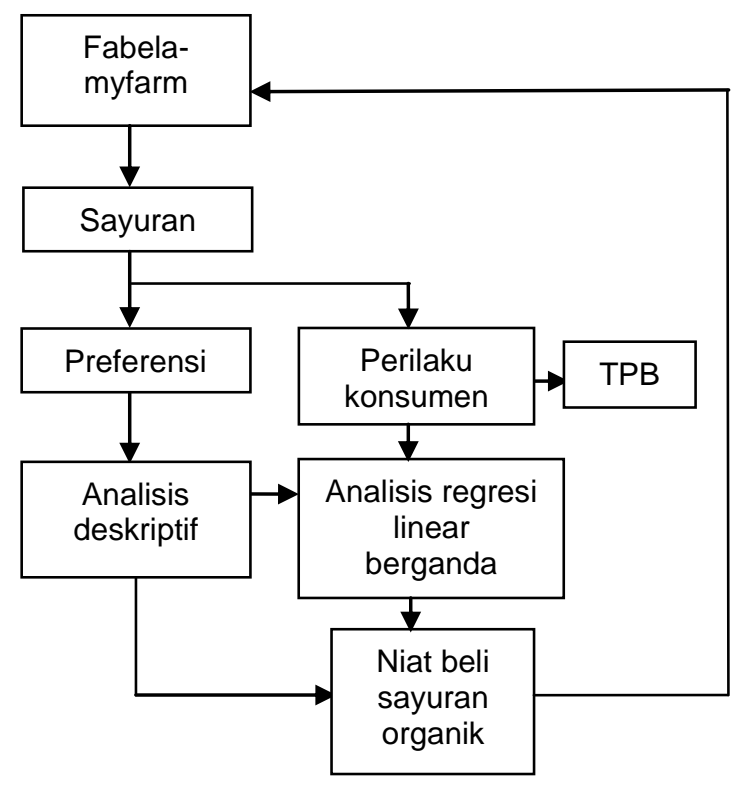

Gambar 3. Kerangka pemikiran penelitian

Penelitian ini dilakukan untuk melihat preferensi konsumen terhadap niat pembelian pada sayuran organik. Karena seiring meningkatnya permintaan sayuran organik Fabela-Myfarm, maka perusahaan memerlukan pemetaan permintaan konsumen yang efektif untuk memenuhi kebutuhan sayuran organik. Salah satunya dengan analisa preferensi konsumen, agar perusahaan dapat menganalisis niat pembelian konsumen dan menyusun strategi pemasaran yang dapat meningkatkan penjualan sayuran organik.

Perumusan masalah pada penelitian ini, sayuran organik merupakan produk belum banyak dikenal oleh masyarakat luas, karena harganya lebih mahal dibandingkan sayuran konvensional yang kurang memengaruhi kesadaran sebagian masyarakat dalam menerapkan gaya hidup sehat dengan mengonsumsi sayuran tanpa bahan kimia. Perubahan konsumsi merubah pola pembelian dari segi perilaku konsumen. Potensi pasar untuk produk apapun, termasuk sayuran organik sama dengan jumlah orang yang menginginkan atau membutuhkannya dan juga memiliki sumber daya yang diperlukan untuk membelinya (Engel et al., 2012). Kondisi ini dapat dimanfaatkan oleh Fabela-Myfarm untuk yang dihasilkannya menyusun strategi pemasaran yang dapat meningkatkan penjualan sayuran organik. Berdasarkan uraian di atas, maka permasalahan penelitian ini dapat dirumuskan sebagai berikut: Bagaimana preferensi konsumen terhadap atribut sayuran organik? dan Implikasi strategi pemasaran yang dapat meningkatkan penjualan sayuran organik di Fabela-Myfarm?
Tujuan penelitian ini menganalisis berdasarkan latar belakang dan perumusan masalah yang telah dijelaskan, maka tujuan penelitian ini adalah menganalisis preferensi konsumen terhadap atribut sayuran organik di Fabela-Myfarm dan merekomendasikan implikasi strategi yang dapat dilakukan Fabela-Myfarm untuk meningkatkan penjualan sayuran organik, yang dihasilkannya.

\section{METODE PENELITIAN}

Penelitian dilakukan di Fabela My-Farm di Gunung Picung, Bogor, Jawa Barat, dengan waktu selama tiga bulan yaitu dari bulan Mei-Juli 2017. Data yang digunakan adalah data primer dan sekunder. Data primer diperoleh dengan cara observasi dilapangan dan wawancara terstruktur dengan menggunakan alat bantu kuisioner. Data sekunder diperoleh dari studi pustaka, instansi, dan kelembagaan lainya.

Pengambilan contoh dalam penelitian ini menggunakan teknik purposive sampling. Responden merupakan pelangan yang pernah membeli sayuran organik. Berdasarkan pendekatan tersebut, maka dalam menentukan jumlah contoh yang akan digunakan dalam penelitian ini digunakan ketentuan sebagai berikut (Suharjo, 2006):

$Z=95 \%$ (tingkat kepercayaan 95\%)

$p=50 \%$ (proporsi contoh 50\%)

$e=7 \%$ (sampling error $7 \%$ )

$$
n=\frac{1.96^{2} \times 0.5(1-0.5)}{0.07^{2}}=196
$$

Berdasarkan perhitungan, maka ukuran contoh minimum yang digunakan sebanyak 196 responden, yang dibulatkan menjadi 200 responden.

Pengolahan data pada penelitian ini dilakukan dengan beberapa analisis. Analisis yang digunakan antara lain menggunakan analisis deskriptif dan analisis Regresi Linear Berganda.

1. Analisis Deskriptif

Nazir (2002), analisis deskriptif merupakan suatu metode dalam meneliti status kelompok manusia, suatu obyek, suatu set kondisi, suatu sistem pemikiran, ataupun suatu kelas peristiwa pada masa sekarang. Tujuannya adalah untuk membuat deskripsi, gambaran atau lukisan secara sistematis, faktual dan akurat, mengenai faktafakta, sifat-sifat dan hubungan antar fenomena yang diselidiki. Pada penelitian ini, analisis deskriptif digunakan untuk mengidentifikasi 
karakteristik konsumen yang tidak melakukan pembelian sayuran organik.

\section{Analisis Regresi Linear Berganda}

Analisis regresi linear berganda adalah analisis yang digunakan untuk mengukur pengaruh dua atau lebih variabel independen terhadap satu variabel dependen (Sarjono dan Julianita, 2011). Bentuk permodelan regresi linear berganda pada penelitian ini adalah:

$$
Y_{i}=\beta 0+\beta 1 X 1 i+\beta 2 X 2_{i}+\beta 3 X 3_{i}+\varepsilon i
$$

Keterangan:

$\mathrm{Y}=$ variabel niat beli sayuran organik

$\beta 0=$ intersep

$\beta \mathrm{i}=$ nilai parameter koefisien, dimana $\mathrm{i}=1,2,3$

$\mathrm{X} 1=$ variabel sikap terhadap pembelian sayuran organik

$\mathrm{X} 2=$ variabel norma subjektif

$\mathrm{X} 3=$ variabel persepsi pengendalian perilaku

$\varepsilon \mathrm{i}=$ residual

Dalam penelitian ini, variabel sikap terhadap pembelian sayuran organik (X1), variabel norma subjektif $(\mathrm{X} 2)$, dan variabel persepsi pengendalian perilaku $(X 3)$ sebagai variabel yang memengaruhi variabel niat beli sayuran organik (Y) dengan menggunakan pendekatan konsep Theory of Planned Behaviour. Berdasarkan teori tersebut, diasumsikan hubungan ketiga variabel tersebut $(\mathrm{X} 1, \mathrm{X} 2, \mathrm{X} 3)$ berbanding lurus dengan variabel niat beli sayuran organik.

\section{HASIL DAN PEMBAHSAN}

\section{Analisis Deskriptif}

Terdapat dua aspek informasi awal yang diperoleh dari responden, yaitu demografi responden serta tahapan keputusan konsumen sayuran organik. Penelitian ini melibatkan responden sebanyak 200 orang yang terdiri dari responden yang melakukan pembelian produk sayuran organik dalam kurun waktu enam bulan terakhir.

Untuk aspek demografi, responden perempuan pada penelitian ini sebanyak $(77,5 \%)$ dan laki-laki $(22,5 \%)$, status pernikahan responden sebanyak $(81,5 \%)$ sudah menikah dan $(18,5 \%)$ belum menikah dengan rentang usia 20-35 tahun (67\%). Pendidikan terakhir reponden sebagian besar adalah sarjana (71\%). Jenis pekerjaan responden sebagian besar adalah pegawai swasta
$(47 \%)$, jumlah anggota keluarga responden terbesar dengan jumlah 3 orang (33\%).

Untuk aspek keputusan konsumen, didapatkan delapan informasi berdasarkan kuesioner responden. Pada tahap pengenalan kebutuhan, disimpulkan bahwa konsumen sayuran organik yang mengonsumsi untuk kesehatan (75\%), dengan manfaat untuk kebutuhan gizi yang terjamin $(75 \%)$. Untuk tahap pencarian informasi, diketahui bahwa iklan/promosi untuk sayuran organik $(88 \%)$, teman merupakan tempat pertama kali responden mendapatkan informasi mengenai sayuran organik (53\%), dengan fokus perhatian mengenai manfaat kesehatan dari mengonsumsinya $(71,5 \%)$. Tahap evaluasi alternatif menghasilkan informasi bahwa sebagian besar responden melakukan evaluasi dengan fokus pada atribut manfaat kesehatan (58\%), serta harga merupakan hal yang paling menentukan mutu produk $(65,5 \%)$ sebelum melakukan pembelian sayuran organik. Pada tahap keputusan pembelian, sebanyak (40\%) responden menyatakan bahwa kapan terakhir kali membeli sayuran organik, dengan penggunaan satu minggu yang lalu $(40 \%)$, responden menyatakan bahwa sayuran organik yang terakhir dikonsumsi bayam (38\%), responden menyatakan diri sendiri merupakan pihak yang berpengaruh dalam pembelian sayuran organik $(72,5 \%)$.

Tahap konsumsi responden memakan sayuran organik hampir tiap hari $(46 \%)$, jenis sayuran organik yang paling banyak digemari oleh responden bayam $(36,5 \%)$ dan di masak dalam bentuk sayur $(21,5 \%)$. Pada tahap sikap responden mendapatkan manfaat dari mengkonsumsi sayuran organik (100\%), yaitu sangat menyadari pentingnya pola hidup sehat. Tahap kepuasan menentukan produk sebelum melakukan pembelian sayuran, kepuasan konsumen terhadap kualitas sayuran (100\%) karena manfaat yang didapatkan sangat banyak bagi kesehatan tubuh. Pada tahap ke delapan, yaitu loyalitas, sebesar $(44,5 \%)$ responden menyatakan apabila sayuran organik yang dibeli tidak ada akan membeli sayuran lain, responden menyatakan akan setia terhadap sayuran organik $(78 \%)$, jika harga sayuran organik mengalami kenaikan responden menyatakan akan tetap membeli sayuran organik $(74 \%)$, responden merasa puas terhadap pembelian sayuran organik $(81 \%)$ dan sebesar (100\%) menyatakan bersedia merekomendasikan produk tersebut kepada orang lain. 


\section{TPB (Sikap terhadap Perilaku, Norma Subjektif, Persepsi Pengendalian Perilaku, dan Niat Pembelian)}

Sikap terhadap perilaku dalam penelitian ini merupakan sikap terhadap perilaku atau tindakan penggunaan pestisida organik. Sikap terhadap perilaku memiliki dua komponen, yaitu: keyakinan perilaku dan evaluasi (Ajzen, 1991). Sikap terhadap pembelian sayuran organik terdiri atas dua komponen, yaitu keyakinan perilaku dan evaluasi konsekuensi. Proporsi jawaban terbanyak pada komponen keyakinan perilaku yaitu responden setuju bahwa akan lebih sehat mengonsumsi sayuran organik. Hal ini menunjukkan keinginan konsumen untuk mengonsumsi sayuran organik. Dua manfaat yang paling diyakini dalam pembelian sayuran organik adalah keyakinan normatif dan evaluasi konsekuensi.

Norma subjektif terdiri atas komponen keyakinan normatif dan motivasi mematuhi. Proporsi terbanyak pada komponen keyakinan normatif adalah kurang setuju bahwa ada saran atau promosi untuk membeli sayuran organik dari keempat referensi. Proporsi kurang setuju terbanyak secara berurutan, yaitu iklan layanan masyarakat, komunitas ibu rumah tangga, acara memasak di televisi, dan penjual sayuran langganan. Hal ini menunjukkan bahwa responden tidak merasakan adanya dorongan dari lingkungan sosial untuk membeli sayuran organik.

Proporsi terbanyak pada komponen motivasi mematuhi berada adalah jawaban kurang setuju pada setiap pernyataan. Proporsi terbanyak untuk mengikuti saran/promosi membeli sayuran organik secara berurutan, yaitu pada referensi orang tua.

Persepsi pengendalian perilaku terdiri atas komponen keyakinan pengendalian dan kekuatan faktor pengendalian. Proporsi terbanyak pada komponen keyakinan pengendalian adalah jawaban setuju pada faktor ketersediaan sayuran organik di pasar terdekat yang dapat memudahkan pembelian sayuran. Sebagian besar responden juga setuju bahwa harga sayuran organik yang sangat mahal dapat mendorong pembelian sayuran non-organik.

Niat beli sayuran organik diukur dengan empat pernyataan niat beli. Proporsi terbanyak yaitu jawaban setuju bahwa responden berniat membeli sayuran organik dalam frekuensi yang rutin. Sebagian besar responden setuju akan membeli dan menambah konsumsi sayuran organik dalam enam bulan kedepan.

\section{Faktor yang Berpengaruh terhadap Niat Beli Sayuran Organik}

Model regresi linear berganda digunakan untuk mengidentifikasi faktor-faktor yang berpengaruh terhadap niat beli sayuran organik. Nilai $\mathrm{R}^{2}$ pada model yang diperoleh $38 \%$, artinya sebanyak $38 \%$ keragaman variabel niat beli sayur organik dapat dijelaskan oleh keragaman variabel independen dalam model, dan sisanya (62\%) dijelaskan oleh variabel lain yang tidak dimasukkan ke dalam model (Tabel 2).

Tabel 2. Hasil regresi terhadap niat beli sayuran organik

\begin{tabular}{lcc}
\hline \multicolumn{1}{c}{ Variabel } & $\begin{array}{c}\text { Koefisien } \\
\text { Parameter }\end{array}$ & Sig. \\
\hline (Constant) & 1,096 & 0,000 \\
X $_{1}$ (Sikap terhadap Perilaku & 0,074 & 0,112 \\
Sayuran Organik) & & \\
X2 (Norma Subjektif) & 0,223 & $0,000^{*}$ \\
X3 (Persepsi Pengendalian & 0,411 & $0,000^{*}$ \\
Perilaku) & & \\
\hline
\end{tabular}

Keterangan : *Nyata pada taraf $\alpha=5 \%$

R-Square $\quad 0,38$

Persamaan fungsi sayuran organik yang diperoleh adalah:

$$
Y=1,096+0,074 X_{1}+0,223 X_{2}+0,411 X_{3}
$$

Beberapa asumsi yang menunjukkan bahwa model regresi tersebut baik, diantaranya adalah berdistribusi normal, tidak mengalami multikolinieritas, autokorelasi dan heteroskedastisitas. Berikut adalah hasil uji dalam menganalisis faktor-faktor atau karakteristik lingkungan yang memengaruhi harga:

1. Uji Normalitas

Uji normalitas betujuan untuk melihat apakah data terdistribusi normal atau tidak, dengan menggunakan uji Kolomogorov-Spirnov dengan menggunakan software SPSS 23. Nilai Asymp.Sig. (2-tailed) yang didapat yaitu sebesar 0.200 atau lebih besar dari taraf nyata 5\%, maka data dalam model regresi terdistribusi normal.

\section{Uji Multikolinieritas}

Uji multikolinieritas bertujuan untuk menentukan apakah dalam suatu model regresi linier terdapat korelasi antar variabel bebas. Uji multikolinieritas dilakukan dengan cara melihat nilai Variance Inflation Factor (VIF). Nilai VIF yang didapat juga kurang dari 10. Oleh karena itu, hasil tersebut menunjukkan bahwa tidak ada pelanggaran dalam penelitian ini. 


\section{Uji Autokorelasi}

Uji Autokorelasi menurut Juanda (2009) bertujuan untuk mencari tahu apakah kesalahan (errors) suatu data pada satu objek pengamatan berkorelasi dengan objek pengamatan lainnya. Ada atau tidaknya autokorelasi dapat diketahui demgan uji Durbin-Watson (DW). Hasil olahan data menunjukkan bahwa nilai DW sebesar 2,009. Nilai DW yang berada di antara selang 1,55- 2,46 menunjukkan tidak adanya autokorelasi (Firdaus, 2004). Oleh karena itu, hasil tersebut menunjukkan bahwa model tidak mengalami autokorelasi.

\section{Uji Heteroskedastisitas}

Penentuan ada atau tidaknya heteroskedastisitas adalah dengan melihat Grafik Scatterplot. Grafik Scatterplot dalam peneltian ini menunjukkan titik-titik yang menyebar secara acak. Hal tersebut menunjukkan bahwa model dalam penelitian ini tidak mengalami heteroskedastisitas.

Nilai koefisien parameter $\left(\beta_{j}\right)$ pada variabel sikap terhadap pembelian sayuran organik (X1), variabel norma subyektif (X2), dan variabel persepsi pengendalian perilaku (X3) lebih dari 0 (Tabel 2), artinya model yang diperoleh sesuai dengan asumsi pada Theory of Planned Behavior. Namun hanya variabel norma subjektif (X2) dan variabel persepsi pengendalian perilaku (X3) yang signifikan berpengaruh terhadap niat sayuran organik pada $\alpha=0.05$.

Variabel $\mathrm{X}_{2}$ dan $\mathrm{X}_{3}$ merupakan variabel yang berpengaruh nyata terhadap niat beli sayuran organik. Setiap peningkatan 1 skor norma subyektif $\left(\mathrm{X}_{2}\right)$ akan meningkatkan 0,223 skor niat beli sayuran organik (Y), ceteris paribus. Setiap peningkatan 1 skor persepsi pengendalian perilaku $\left(X_{3}\right)$ akan meningkatkan 0,411 skor niat beli sayuran organik $(Y)$, ceteris paribus. Persamaan niat beli sayuran organik yang diperoleh menguatkan analisis deskripitif model TPB di atas.

Berdasarkan tabel persepsi pengendalian perilaku memiliki pengaruh yang paling besar pada niat pembelian sayuran organik, hal ini terlihat dari nilai koefisien 0,411, dikarenakan konsumen dalam membeli sayuran organik ingin mendapatkan berbagai macam manfaat.

\section{Implikasi Manajerial}

Potensi pertanian organik tergolong besar, karena memberikan prospek ekonomi dan layak untuk diusahakan oleh petani pada umumnya dan Fabela-Myfarm sebagai perusahaan berbadan hukum UD yang sedang bertransformasi menjadi
CV dan nantinya sebagai PT yang mengusahakan pertanian dan penjualan sayuran organik. Dalam hal ini pengembangan usaha sayuran organik dialihkan pada upaya pengembangan produksi sesuai dengan kebutuhan, karena dari hasil penelitian didapatkan bahwa persepsi pengendalian perilaku dan norma subyektif berpengaruh nyata dan positif terhadap niat beli sayuran organik yang diproduksi UD Fabela-Myfarm. Disisi lain pembelian sayuran organik tidak berpengaruh, tetapi memberikan indikasi positif dari konsumen untuk mengkonsumsi sayuran organik yang diproduksi UD Fabela-Myfarm.

Hal efektif dari pengembangan usaha sayuran organik pada UD Fabela-Myfarm adalah memerhatikan faktor-faktor internal maupun eksternal yang terdapat dalam hasil penelitian dengan analisis regresi linear berganda yang ditunjukkan oleh variabel nyata seperti persepsi pengendalian perilaku dan norma subjektif sebagai representasi kekuatan dan peluang preferensi konsumen terhadap produk sayuran organik secara khusus. Berdasarkan kedua kondisi tersebut dapat disusun strategi pemasaran yang terkait dengan produksi (jenis sayuran organik yang ditawarkan), harga (kemajuan daya beli yang diikuti dengan tingkat ketersediaan), distribusi (keterjangkauan lokasi beserta cara pengiriman) dan promosi (informasi produk yang menarik dan media yang digunakan).

Strategi tersebut berguna untuk mengaitkan konsumen dari sisi kuantitas, mutu dan keseimbangan yang mampu memberikan keuntungan lebih baik dari waktu ke waktu, yang dicerminkan dari kepuasan konsumen yang mengulang pembelian produk sayuran organik yang ada, disamping berminat membeli produk sayuran organik yang baru dimunculkan sebagai bentuk diversifikasi pembelian dan loyalitas konsumen yang pernah pertama kali hingga saat ini membeli sayuran organik. Secara spesifik hal tersebut erat kaitannya dengan penguasaan pengetahuan tentang konsumen sayuran organik yang direpresentasikan oleh keinginan dan kebutuhannya secara akurat, tepat dan utuh.

\section{KESIMPULAN}

Berdasarkan hasil analisis yang dilakukan pada penelitian ini diperoleh beberapa informasi, yaitu pada karakteristik konsumen sayuran organik di Bogor, didapatkan bahwa sebagian besar konsumen berjenis kelamin perempuan 
yang berada pada rentang usia 20-35 tahun dengan status menikah dan memiliki jumlah anggota keluarga 2-4 orang. Alasan utama konsumen membeli sayuran organik adalah karena kandungan gizi yang lebih baik dari sayuran konvensional dengan fokus perhatian dan pertimbangan utama konsumen pada kualitas produk dan manfaat kesehatan serta majalah/ koran menjadi sumber informasi utama. Di lihat dari pekerjaan dan pendapatan keluarga, sebagian besar konsumen sayuran organik berstatus bekerja dan memiliki pendapatan keluarga relatif tinggi, yaitu lebih dari Rp3.000.000 per bulannya.

Konsumen sayuran organik memperoleh informasi tentang sayuran organik melalui media cetak yaitu koran dan majalah. Meski demikian, sumber informasi yang paling berpengaruh dalam memilih sayuran organik adalah teman dan kemudian informasi dari internet (media sosial). Sebagian besar konsumen menyatakan tidak dipengaruhi oleh kelompok acuan dalam memilih sayuran organik.

Konsumen melakukan evaluasi pasca pembelian sayuran organik. Hal lainnya yang ditunjukan sebagian besar konsumen menyatakan puas setelah mengonsumsi sayuran organik. Dilihat dari alasan pembelian ulang, mayoritas konsumen melakukan pembelian ulang sayuran organik karena merasakan manfaat yang baik bagi tubuh, tingkat kepuasan yang tinggi pada sayuran organik diiringi dengan tindakan merekomendasikan orang lain untuk ikut mengkonsumsi sayuran organik, dimana mayoritas konsumen menyarankan orang lain mengkonsumsi sayuran organik.

\section{DAFTAR PUSTAKA}

Ajzen, I. 1991. The theory of planned behavior. J Organizational Behavior and Human Decision Processes. 50 (2): 179-211.

Badan Standarisasi Nasional. 2002. Sistem Pangan, Standar Nasional Indonesia. Jakarta (ID): Badan Standariasi Nasional.

[BPS] Badan Pusat Statistik. 2015. Jumlah Penduduk Kota Bogor. Jakarta (ID): BPS

[BPS JABAR] Badan Pusat Statistik Jawa Barat 2016. Pengeluaran rata-rata perkapita sebulan provinsi Jawa Barat. Jakarta (ID): BPS

Barus, M.A. 2005. Analisis Faktor-faktor yang Mempengaruhi Permintaan Beberapa Sayuran Organik, di PT Amani Mastra
[Skripsi]. Bogor: Fakultas Pertanian, Institut Pertanian Bogor.

Budinono, E. 2005. Analisis Persepsi dan Preferensi Konsumen Pasar Swalayan Superindo Depok [Tesis]. Bogor (ID): Institut Pertanian Bogor.

Damayanti, R. 2009. Analisis Preferensi Konsumen Wortel Organik Amani Mastra di Foodmart Ekalokasari [tesis]. Bogor (ID): Fakultas Pertanian, Institut Pertanian Bogor.

Engel, J.F., R.D. Blackwell, P.W. Miniard. 2012. Consumer Behavior. Canada (US): Cengage Learning

Firdaus, M. dkk. 2004. Perkoperasian, Sejarah, Teori dan Prakt. Bogor: Penerbit Ghalia Indonesia

Hubeis, M. 2013. Prospek Pangan Organik Bernilai Tambahan Tinggi Berbasih Petani, Bogor (ID): PT Penerbit IPB Press.

Juanda, B. 2009. Ekonometrika Pemodelan dan Pendugaan. IPB Press, Bogor.

Muljaningsih, S. 2011. Preferensi konsumen dan produsen produk organik di Indonesia. Ejurnal 14(4): 1-5.

Nazir, M. 2002. Metode Penelitian. Bogor (ID): Ghalia Indonesia.

Santoso, S., F. Tjiptono. 2001. Riset PemasaranKonsep dan Aplikasi dengan SPSS. Jakarta (ID): PT Elex Media Komputindo.

Sarjono, H. dan W. Julianita. 2011. SPPS vs LISREL: Sebuah Pengantar, Aplikasi untuk Riset. Salemba Empat, Jakarta.

Setiadi, N.J. 2010. Perilaku Konsumen: Perspektif Kontemporer pada Motif, Tujuam, dan Keinginan Konsumen. Jakarta (ID): Kencana.

Schiffman, L.G., L.L. Kanuk. 2010. Consumer Behaviour Tenth Edition. New Jersey (US): Pearson Education.

Sudiyanti. 2009. Predicting women purchase intention for green food products in Indonesia [tesis]. Norway: University of Agder.

SNI 6729. 2010. Standar Nasional Indonesia. Kementerian Pertanian RI, Jakarta.

Suharjo, B. 2006. Sampling Technique. Jakarta: Mars School of Marketing $\mathcal{E}$ Research

Sumarwan, U., A. Noviandi, K. Kibrandoko. 2013. Analisis Proses Keputusan Pembelian, Persepsi dan Sikap Konsumen Terhadap Beras Organik di Jabotabek. Jurnal Pangan. 22(2): 1-17. 
Sumarwan, U. 2011. Pemasaran Strategik Perilaku Konsumen dan Marketing Plan. Bogor (ID): PT penerbit IPB Press

Sumarwan, U. 2014. Perilaku Konsumen: Teori dan Penerapannya dalam Pemasaran. Ed ke-2. Jakarta (ID): Ghalia Indonesia.
Tjiptono, F. 2002. Manajemen Jasa. Yogyakarta (ID): Andi.

Umar, M. 2004. Pengendalian Mutu Produksi Sayuran Organik Pada Yayasan Bina Sarana Bakti. Bogor (ID): Institut Pertanian Bogor 